\title{
Gruzijos saugumo strategijos plètra: sunkus kelias NATO link
}

\begin{abstract}
Gruzijos saugumo užtikrinimo alternatyvos pastaraisiais metais susiaurëjo iki labai aiškaus tikslo - tapti NATO aljanso nare. Toks pasirinkimas logiškas mažai valstybei. Vis dèlto saugumo strategija, kuri paremta aljanso su stipresne valstybe siekiu, gali kelti ir tam tikru problemų. Gruzijos atveju saugumo užtikrinimo dilemos yra dar sudètingesnès. Neišspręstos separatistiniu konfliktu problemos ilgą laiką trukdẻ Gruzijai tapti patikima NATO kandidate. Kuo labiau Gruzija siekė narystės NATO, tuo labiau tam priešinosi Rusija. İtampos kulminacija tapo 2008 m. rugpjūčio karas tarp Gruzijos ir Rusijos. Karo rezultatai tarsi leido Gruzijai išspręsti vidines dilemas, tačiau anaiptol nesuteikè garantiju dèl narystės NATO. Straipsnyje analizuojama, ar narystės NATO siekis Gruzijai tikrai gali garantuoti saugumą. Taip pat aptariamos pagrindinès kliūtys, trukdančios realizuoti Gruzijos saugumo strategiją, ir esminės dilemos, su kuriomis susiduria NATO, svarstydamas Gruzijos narystės perspektyvas.
\end{abstract}

\section{İvadas}

Rusijos ir Gruzijos karas Pekino olimpiados metu atskleide pačias skaudžiausias Gruzijos saugumo dilemas. Nuo pat Sovietų sajungos subyrẻjimo ir Gruzijos nepriklausomybės paskelbimo $1991 \mathrm{~m}$. Gruzija vis dar tebesprendžia savo nacionalinio saugumo ir teritorinio integralumo problemas. Rusijos agresija ir grubus suvereniteto nepaisymas patvirtino daug kartų Gruzijos valdžios išsakytus nuogąstavimus, kad šiame regione ičsaldyti konfliktai bet kada gali virsti tiesioginiais karo veiksmais. Tai, kas XXI a. atrodè beveik neįmanoma, tapo skaudžia realybe. Rusijos pajegoms skverbiantis vis giliau į Gruzijos teritoriją iškilo net grèsmė, kad suvereni demokratiška valstybė gali būti visiškai okupuota kitos valstybès. Po to, kai Rusija vienašališkai pripažino Pietų Osetijos ir Abchazijos nepriklausomybę, Gruzija visiškai pagrįstai gali kaltinti Rusiją tikslingu Gruzijos skaldymu.

Gruzijos valdžia per viso pasaulio žiniasklaidą ragino tarptautinę bendruomenę nenusigręžti nuo agresiją patiriančios valstybės. Rusijos agresija

\footnotetext{
${ }^{*}$ Dr. Tomas Janeliūnas - Vilniaus universiteto Tarptautinių santykių ir politikos mokslų instituto docentas. Laura Kirvelytè - Vilniaus universiteto Tarptautinių santykių ir politikos mokslų instituto absolventè. Adresas: Vokiečių g, 10, 01130 Vilnius; tel. 85 2514130, el. paštas - tomas.janeliunas@tspmi.vu.lt, laura. kirvelyte@gmail.com.
} 
tarsi turëjo patvirtinti, kad Gruzija ne veltui siekẻ kuo greičiau užsitikrinti kolektyvinio saugumo garantijas ir tapti NATO nare. Nuo "Rožių revoliucijos" ir Michailo Saakašvilio tapimo Gruzijos prezidentu ši maža Pietų Kaukazo valstybė aiškiai pasirinko sudètingą kelią NATO link. Tai kèlė didelį nepasitenkinimą Rusijai ir galvos skausmą daugeliui NATO narių. Kaip atskleidè NATO susitikimas Bukarešte $2008 \mathrm{~m}$. pavasarį, dalis NATO narių nenorejo erzinti Rusijos ir suteikti narystės veiksmų planą Ukrainai ir Gruzijai.

Konfliktas privertè daugelį NATO ir ES šalių įvertinti Rusijos veiksmus ir santykius su Maskva. NATO atstovai ir net ištikimiausios Rusijos partnerès Europoje (tarkime, Vokietija) suskubo pareikšti, kad konfliktas neužbraukia Gruzijos galimybių tapti NATO nare. Vis dèlto, kol nèra jokių oficialių sprendimų dèl Gruzijos perspektyvų tapti NATO nare, išlieka daug abejoniu, ar Gruzija tikrai gaus NATO saugumo garantijas. Aprimus pirmosioms emocijoms, tapo aišku, kad NATO narès, kurios abejojo Gruzijos patikimumu, 2008 m. pabaigoje dar labiau norejjo neskubėti suteikti Narystės veiksmų planą (NVP) Gruzijai (ir Ukrainai). Net JAV atstovai pripažino, kad skubėti suteikti NVP Gruzija reikštų dar labiau aštrinti santykius su Rusija ir mažinti galimybes stabilizuoti situaciją Pietų Kaukazo regione. Todèl prieš 2008 m. gruodžio 2-3 d. numatytą NATO valstybių užsienio reikalų ministrų susitikimą JAV valstybės sekretorè Condoleezza Rice užsiminè, kad JAV nebereikalaus, kad būtų parengtas planas dèl Ukrainos ir Gruzijos prisijungimo prie NATO. Vis dèlto buvo pareikšta, kad narystės NATO perspektyva nėra keičiama, o padėti vykdyti reformas Gruzijoje ir Ukrainoje galima ir be oficialaus Narystès veiksmu plano.

Šiame straipsnyje bus apžvelgti svarbiausi iššūkiai ir grèsmės Gruzijai bei Tbilisio pastangos užtikrinti savo saugumą. Gruzijos saugumo strategijos per nepriklausomybės laikotarpį transformavosi keletą kartų. Kaskart buvo bandoma surasti tinkamą balansą tarp vidinių saugumo problemų ir apsaugos nuo išorinių grèsmių. Surasti tinkamą sprendimą nėra paprasta: Gruzija turi ne tik separatizmo problemu, bet ir didžiuli kaimyną, kuris skatina separatizmą ir manipuliuoja kitos valstybės saugumu.

Dar iki Rusijos ir Gruzijos karo 2008 m. rugpjūčio mèn. Gruzijai buvo iškilusi sunki dilema: ar ryžtingai siekti narystès NATO, bet dẻl Rusijos ambicijų rizikuoti visam laikui prarasti Abchaziją ir Pietų Osetiją; ar nuolaidžiauti Rusijai ir tikètis, kad ši neskatins separatizmo procesų Gruzijoje.

Gruzija pasirinko integraciją i euroatlantines struktūras ir sulaukè agresyvaus Rusijos atsako. Vis dèlto kol kas Gruzijos naryste NATO, ar juo labiau ES tebėra siektinas tikslas. Saugumo prasme Gruzija yra pažeidžiama labiau nei bet kada iki šiol. Todèl natūraliai kyla klausimas, ar Gruzijos pasirinkimas tapti aljanso nare garantuos jai saugumą? Būtent šis klausimas yra svarbiausias. Analizuojant teorines mažos valstybės saugumo užtikrinimo galimybes ir Gruzijos saugumo strategijos kaitą, bus ieškoma atsakymu, ar Gruzijos vadovai tinkamai bando stiprinti savo šalies saugumą.

Straipsnyje bus aptartos svarbiausios priežastys, komplikavusios Gruzijos pastangas užsitikrinti savo nacionalini saugumą, ir tarptautinių veikèju požiūriai į Gruzijos saugumo strategijų ígyvendinimą. 
Gruzijos ir Rusijos karas dar labiau išryškino mažų valstybių poreikį užsitikrinti saugumo garantijas per tarptautines organizacijas ar aljansus. Lietuva itin jautriai reagavo į Rusijos - Gruzijos konfliktą, nes šis karas priminè, kad maža valstybė bet kada gali tapti didžiosios valstybės agresijos ar provokacijos auka. Net ir būdama NATO nare, Lietuva iki šiol nesijaučia visiškai saugi, nes poveikis mažai valstybei gali būti daromas nebūtinai tik karo priemonèmis. Be to, Rusijos ir Gruzijos karo akivaizdoje sustiprëjo ir diskusijos dèl NATO, kaip gynybinio aljanso, funkcijų efektyvumo. Būtent gynybinis solidarumas Lietuvai buvo bene svarbiausia priežastis siekti narystès NATO. Gruzija, siekdama tapti NATO nare, taip pat tikisi taip išspręsti daugumą savo saugumo problemų. Vis dèlto pastangos kuo greičiau įsitraukti į NATO gretas ne tik išryškino vidines Gruzijos saugumo problemas, bet ir atskleidè skirtingą NATO valstybių požiūrị dèl potencialių saugumo įsipareigojimų. Toks NATO susiskaidymas gali kelti ir bendro pobūdžio abejonių dẻl kolektyvinės gynybos efektyvumo - ar tikrai narystė aljanse mažoms valstybėms garantuoja saugumą.

\section{Mažosios valstybès saugumo strategija: galimybès ir ribos}

\subsection{Nesaugumas - nuolatinè mažosios valstybès problema}

Viena pagrindinių mažają valstybę charakterizuojančių savybių - jos pažeidumas: nors kokybiniais rodikliais (BVP vienam gyventojui, perkamosios galios paritetas, vidutinis atlyginimas ir pan.) mažoji valstybė gali net pralenkti didžiają ${ }^{1}$, vis dèlto mažoji valstybè disponuoja nedideliais absoliučiaisiais geografiniais, finansiniais ir žmogiškaisiais ištekliais, todèl yra mažiau atspari išorès spaudimui.

XX a. įvykę tarptautinės sistemos pokyčiai (ypač I pasaulinis karas, kolonijinės sistemos subyrëjimas ir SSRS žlugimas) atvėrè galimybes mažuju valstybių savarankiškumui. Vis dèlto daugelis naujai susikūrusių (ar atkūrusių nepriklausomybę) mažų valstybių iškart atsidūrè „,aukštos geopolitinès įtampos zonoje" - didžiuju galių interesų susikirtimo erdvèje. Taigi, esant tokioms geopolitinėms sąlygoms, mažajai valstybei iškyla poreikis (ir galimybė) savo saugumą užsitikrinti remiantis išoriniu saugumo šaltiniu ar šaltiniais. Stevenas L. Spiegelis pabrèžè, kad tarptautinèje arenoje didžiosios valstybès atlieka galios ir saugumo „tiekëjo“, o mažosios - „vartotojo“ vaidmenį․ „Tiekëją" ir „vartotoją" sieja simbiozinis ryšys: mažoji valstybe gauna „papildomas“ saugumo garantijas, kurios suteikia jai galimybę išsaugoti valstybingumą, o „saugumo tiekèjas" igauna galimybę skleisti savo įtaką ir taip igyti papildomų struktū-

\footnotetext{
${ }^{1}$ Brautigam, D. and Woolcock M., Small states in a global economy. The role of institutions in managing vulnerability and opportunity in small developing countries, United Nations University, July 2001, p. 2 (Discussion paper No. 2001/37).

2 Spiegel, S. L., Dominance and diversity. The international hierarchy, Boston, 1972, p. 133, 136.
} 
rinès galios svertų. Pabrèžtina, kad saugumo šaltiniu gali būti ne tik didžioji valstybè, bet ir kiti dariniai (pvz., ES nèra valstybė, tačiau plačiai pripažįstama kaip tarptautinès arenos veikėjas). Olavas F. Knudsenas šiuo klausimu yra dar radikalesnis, mažąsias valstybes apibūdindamas kaip "grynąsias saugumo importuotojas", t. y. tarptautinès arenos veikëjus, kurie, siekdami užsitikrinti išlikimą, reikalauja daug daugiau paramos iš išorès nei patys gali duoti ${ }^{3}$. Mažosios valstybės saugumas, skirtingai nei didžiosios, yra ypač glaudžiai susijęs su išoriniais veiksniais. Kitaip tariant, vidinis mažosios valstybės stabilumas prisideda prie jos saugumo užtikrinimo, tačiau nẻra ji lemiantis veiksnys.

Išorinis saugumo šaltinis mažoms valstybėms dažniausiai (dèl savų resursų trūkumo) yra gyvybinè būtinybė. Dẻl to mažosios valstybès turi būti lanksčios (t. y. gebėti prisitaikyti): saugumo šaltiniui silpstant, mažoji valstybẻ turi performuoti strategiją ir keisti savo saugumo šaltinius. Lankstumas mažajai valstybei - panašios svarbos parametras kaip galia didžiajai valstybei, nes nuo to priklauso, ar mažoji valstybė sugebės išlikti.

Būtina paminèti ir dar kelias mažosios valstybės saugumui būtinas sąlygas. Tam, kad mažoji valstybė gebėtų užsitikrinti saugumą išorinio saugumo šaltinio dèka, ji turi būti svarbi didžiosioms galioms (objektyvusis kriterijus) arba pateikti save kaip svarbią didžiosioms galioms ir įtikinti pastarąsias savo svarbumu (subjektyvusis kriterijus). Priešingu atveju mažajai valstybei būtų sunku užsitikrinti ilgalaikị dèmesị ir saugumo garantijas iš didžiosios galios, potencialaus saugumo šaltinio. Kaip vèliau bus atskleista straipsnyje, būtent Gruzijos svarbos Vakarams (ypač JAV) akcentavimas ir nuolatinis „dèmesio reikalavimas" tapo vienu ryškiausių Gruzijos saugumo politikos akcentų.

\subsection{Saugumo strategija - mažosios valstybès elgsenos refleksija}

Akademinëje erdvëje netyla diskusijos, ar mažosios valstybės yra pajègios savarankiškai rinktis savo užsienio ir saugumo politikos kryptis, ar už jas „nusprendžia“ didžiosios tarptautinès arenos galios. Šioje diskusijoje patraukliausia „vidurio“ pozicija, kuri teigia, kad, nors didžiujų valstybiu politikos ir apriboja mažosios valstybės veiksmų laisvę, galutinis pasirinkimas užsienio ir saugumo politikos srityje priklauso nuo pačios mažosios valstybės.

Šiame straipsnyje bus remiamasi tokiu saugumo strategijos apibrěžimu: tai valstybės ilgalaikių politinių pasirinkimų visuma, fiksuojama strateginiuose užsienio ir saugumo politikos dokumentuose (nacionalinio saugumo koncepcijoje, užsienio politikos strategijoje, karinejje strategijoje ar kituose) bei besireiškiantis politinèje praktikoje. Būtina pastebėti, kad strateginiuose dokumentuose užfiksuotos nuostatos ne visada atitinka politinę praktiką. Todèl ilgalaikè, nuolatinè ir pasikartojanti valstybės saugumo politikos praktika turètų būti analizuojama kaip svarbiausias kriterijus, atspindintis valstybès saugumo strategiją.

Knudsen, O. F., „Small states, latent and extant: towards a general perspective“, JIRD, 2002, no. 5 (2), p. 187. 
Saugumo strategija atlieka dvejopą funkciją. Visu pirma, ji „,informuoja" kitus tarptautinès arenos veikëjus apie konkrečios valstybės užsienio ir saugumo politikos kryptis ir dèl to didina valstybès politikos skaidrumą bei nuspèjamumą tarptautinèje arenoje. Būti prognozuojamu tarptautiniu santykių veikëju mažajai valstybei labai svarbu, nes nuspejjamumas susijęs su valstybès struktūrine galia, o ši - su galios disbalanso mažinimu. Antra, saugumo strategija, ypač jei fiksuojama strateginiuose dokumentuose, leidžia užtikrinti užsienio ir saugumo politikos tęstinumą bei minimizuoti realaus pagrindo neturinčias jos modifikacijas (kada išorinė valstybės padètis nekinta, o pasirinkta saugumo strategija veikia sklandžiai) valdančiojo elito kaitos metu. Nors saugumo strategija gali užtikrinti valstybės užsienio ir saugumo politikos krypčių stabilumą, ji nẻra statiška. Valstybè per kasdieninę politinę praktiką gali modifikuoti pasirinktą saugumo strategiją taip, kad ji geriausiai atitiktų valstybės saugumo interesus.

Labai svarbu pažymèti ir tai, kad valstybès saugumo strategija paprastai susideda iš dviejų kategorijų. Saugumo strategijos pagrindas - mažosios valstybės pasirinktos užsienio ir saugumo politikos kryptys, kurias pripažįsta „saugumo šaltinis“ (konkrečios saugumo garantijos). Tačiau jei saugumo strategija vadintume tik jau turimas (fiksuotas) saugumo garantijas, ji taptų labai siaura sąvoka. Todèl ne mažiau svarbus yra ir valstybės aspiracijų aspektas: jei mažoji valstybe tikslingai siekia saugumo garantijų iš tam tikro saugumo šaltinio, egzistuoja tikimybe், kad ji jas vieną dieną gaus, nes saugumo garantiju suteikimas - abipusis procesas tarp "saugumo vartotojo" ir "saugumo tiekejjo". Taigi, galima teigti, kad ilgalaikiai valstybès interesai ir siekiai apima tiek jau esamas garantijas, tiek valstybès aspiracijas.

Aljansas - viena populiariausių mažosios valstybės saugumo strategijų (taip pat įprastomis mažujų valstybių saugumo strategijomis laikoma neutralitetas bei komplementarizmas). Aljanso saugumo strategija gali igauti sajungos su didžiąja valstybe, mažuju valstybiu aljanso ir mišraus (mažujų ir didžiujuc valstybiuc) aljanso formas ${ }^{4}$. Pagrindinis aljanso privalumas - aiškiai apibrèžta užsienio politikos kryptis, tikslai ir prioritetai. Dèl aiškaus ",saugumo tiekèjo" apibrèžimo daug lengviau pasiekiamas politinis konsensusas valstybės viduje dèl užsienio ir saugumo politikos krypčiu, o tai yra labai svarbu mažajai valstybei, nes tada politinio elito rotacija nekelia grèsmès saugumo strategijos tęstinumui. Be to, pasirinkus aljanso partnerị (partnerius), valstybė gali (bent jau tam tikrą laiką) būti rami dèl savo saugumo užtikrinimo, todèl jai nebūtina nuolat ieškoti saugumo garantijų. Kita vertus, didžiausias šios strategijos trūkumas - alternatyvų nebuvimas silpstant saugumo „šaltiniui“. Tai gali versti ieškoti naujo saugumo "tiekejjo“ arba keisti visą strategiją. Tam tikra priklausomybė nuo pasirinkto aljanso partnerio galimybių (ir net jo pasirenkamų strateginiu uždaviniu) ilgainiui gali supančioti mažają valstybę ir padaryti ją didesnès galios nuosmukio ar pakitusios strategijos įkaite.

\footnotetext{
4 Wiberg, H., „, The security of small nations: challenges and defences“ in Journal of Peace Research, 1987, Vol. 24, No. 4, p. 343.
} 
Tam tikrą laiką abejojusi ir balansavusi, po $2003 \mathrm{~m}$. Gruzija pasirinko kaip tik aljanso su NATO (ir ypač intensyvių santykių su JAV) strategiją. Šis pasirinkimas nebuvo lengvas tiek dèl vidinės Gruzijos saugumo situacijos, tiek dèl sudètingų išorinių aplinkybių. Nors šiuo metu yra labai aiškios Gruzijos strateginio pasirinkimo kryptys formaliaja bei praktiniu aspiraciju prasme, kol kas nèra formalių saugumo "tiekèjo“ garantijų. Būtent toks neužpildytas saugumo „paklausos" ir "pasiūlos" santykis šiuo metu kelia daugiausiai nerimo Gruzijai.

\section{Gruzijos saugumo politika iki „Rožių revoliucijos“}

Po Šaltojo karo pabaigos nepriklausomybę atkūrusi Gruzija iškart susidūrè su labai sudètinga saugumo situacija: šalis ne tik turëjo du nesẻkmingus karus su separatistiniais Abchazijos ir Pietų Osetijos regionais bei nuolat susidūrẻ su grèsme teritoriniam integralumui, tačiau ir buvo priversta taikytis su Rusijos ittaka valstybei. Nors laikotarpis po „rožiu revoliucijos“ Gruzijos politiniame gyvenime atrodo kaip ryškus lūžis nuo balansavimo tarp Maskvos ir Vašingtono prie aljanso su Vašingtonu saugumo strategijos, Gruzijos saugumo politiką iki "rožių revoliucijos“ tiksliau būtų apibūdinti kaip nuoseklų èjimą aljanso su Vakarais link. Kaip jau buvo minèta, vienas pagrindiniu aljanso saugumo strategijos požymių - tvirtas konsensusas šalies viduje (tiek tarp politiniu jègų, tiek visuomenejje) dèl šalies užsienio ir saugumo politikos krypčių. Gruzijos atveju skirtumai tarp skirtingų politinių jẻgų reiškèsi tik nacionaliniu klausimu, t. y. sprendimu, kiek laisvès suteikti etninèms mažumoms. Tačiau Rusija nė vienu laikotarpiu nebuvo laikoma patikimu saugumo garantu.

\subsection{Separatistinių regionụ gravitavimas Rusijos link}

Dar perestroikos metu Gruzijoje, kurioje gyveno kelios skirtingų tautybiu grupès (abchazai, osetinai, armènai, azerai, etc.), atsirado pirmieji konfliktai. Intensyviausi konfliktai įvyko su tomis etninėmis mažumomis, kurios neturëjo „motininès“ valstybès ${ }^{5}$. Nors armėnų Samcche Džavacheti regione ar azerų Kvemo Kartlti regione skaičius gerokai lenkẻ abchazų ir osetinų skaičiu, minėtuose regionuose kilusi îtampa tarp etniniu tautų i rimtesnius konfliktus neperaugo. Galima manyti, kad abchazų ir osetinu poreikis užsitikrinti savo saugumą (ir dèl to reikalauti tam tikros autonomijos ar nepriklausomybės nuo Gruzijos) buvo žymiai ryškesnis, nes šios etninès mažumos turëjo mažiau alternatyvu, garantuojančiu deramą egzistavimą.

Svante C., Authonomy and conflict. Ethnoterritoriality and separatism in the South Caucasus - cases in Georgia, Dissertation for the degree of Doctor of Philosophy, Uppsala university, 2002, p. 173. 
Tiek Abchazijos, tiek Pietų Osetijos konfliktai - etninio pobūdžio, kilę dèl nacionalistinès pirmojo Gruzijos prezidento Zviado Gamsachurdijos politikos. Kilusia įtampa netruko pasinaudoti Rusija, o tai ir lėmė konfliktu , „išaldymą“. Kita vertus, patys konfliktai visu pirma kilo dèl vidiniu priežasčiu.

1991 m., Gruzijai atkūrus nepriklausomybę ir pasiskelbus unitarine valstybe (be autonominiu regionu), kilo nesutarimai su Abchazija, kuri Gruzijos SSR turëjo autonominès respublikos statusą. ,„ร̌̌aldyti“ konfliktai posovietinëje erdvèje - fenomenalus reiškinys, kurị lėmè kelios priežastys. Pirma, dauguma šių konfliktų kilo dèl radikalių struktūrinių pokyčių - po SSRS dezintegracijos nepriklausomybę gavo tik sovietinės respublikos, o autonominès respublikos, kuriose gyveno skirtingos etninès tautos - ne. Antra, šie etniniai bei teritoriniai nesutarimai ,išaldyti“" tapo dèl Rusijos įsikišimo.

Abchazija, niekada nebuvusi istorine Gruzijos dalimi, $1931 \mathrm{~m}$. Josifo Stalino buvo inkorporuota ị Gruzijos SSR sudètį. Po SSRS griūties Abchazija, pagal galiojusias taisykles, tapo integralia Gruzijos dalimi. Tačiau XX a. devintojo dešimtmečio pabaigoje etninių abchazu dalis Abchazijoje nesiekè net 20 proc., todèl separatizmo grèsmè tuo metu aktuali neatrodè. Nacionalistinis Gamsachurdijos režimas privertẻ abchazu mažumą sunerimti dèl etninės asimiliacijos. Siekị atsiskirti nuo Gruzijos Abchazijos gyventojai išreiškẻ dar 1989 m. kovą, o susidūrimai su centrine valdžia prasidejjo 1989 m. liepą, Gruzijos valdžiai pamėginus atidaryti Tbilisio universiteto filialą regiono centre Suchumyje. 1992 m., Gruzijos karinèms jègoms įžengus i Abchaziją, prasidèjo kariniai veiksmai. Nors Tbilisis tikëjosi greito karo, kariniai veiksmai užsitęsė iki 1993 metu. Karo su Gruzija metu Abchazija sulauke paramos iš Rusijos (tiek ginklais bei humanitarine pagalba, tiek žmoniškaisiais ištekliais - prie abchazu prisijungè čečènų kovotojai'). 1993 m. spalį Gruzija ir Abchazija pasirašè Rusijos remiamą susitarimą dèl ugnies nutraukimo. Taip pat regione buvo dislokuoti Rusijos taikdariai (su NVS mandatu). Taip konfliktas tapo "ǐ̌saldytu“. ${ }^{7}$

Derybos dèl konflikto sureguliavimo tarp Gruzijos ir Abchazijos buvo dvišalės. Separatistinis regionas reikalavo visiškos nepriklausomybės nuo Gruzijos, Gruzija siūlẻ Abchazijai geriausiu atveju plačią autonomiją. Derybas dèl Abchazijos statuso ilgą laiką stabdè konflikto šalių nesutarimas dẻl pabègèliu grị̌imo: Gruzija teigè pradėsianti svarstyti Abchazijos regiono statusą tik tuomet, kai į regioną bus grąžinti visi pabėgèliai ir perkeltieji asmenys, tuo tarpu Abchazija reikalavo jos statusą apibrèžti iki pabėgèliu grąžinimo, nes baiminosi, kad, šiems grižus, abchazai vèl taps mažuma ir nebegalès efektyviai ginti savo interesu.

Viena didžiausių problemų Abchazijos konflikto sureguliavimo procesegalios asimetrija, sukelta per didelès Rusijos įtakos bei labai menko tarptautinio įsitraukimo. Vienintelè tarptautinè organizacija, formaliai dalyvavusi konflikto

\footnotetext{
${ }^{6}$ Sabanadze N., International involvement in the South Caucasus, European Centre for Minority Issues, February 2002, p. 12 (Working paper no. 15).

7 Lynch D., Why Georgia matters, Institute for Security Studies, February 2006, p. 17-18 (Chaillot paper No. 86).
} 
sureguliavimo procese, buvo Jungtinės Tautos (JT). Tačiau JT įsitraukimas buvo labai menkas. 1992 m., praëjus mėnesiui po karo veiksmų pradžios, JT į regioną pasiuntė faktų rinkimo misiją (angl. fact-finding mission). $1993 \mathrm{~m}$. pavasari buvo paskirtas specialusis JT pasiuntinys Abchazijoje (juo tapo Šveicarijos diplomatas Eduardas Brunneris). Tais pačiais metais Gruzija paprašè JT ST Abchazijoje dislokuoti taikdariu misiją. JT ST prièmė kompromisini sprendimą (nes Rusija - nuolatinė JT ST narè) ir vietoje taikdarių misijos į Abchaziją išsiuntė stebėtojų misiją (angl. United Nations Observer Mission in Georgia - UNOMIG), kurios pagrindinè užduotis buvo stebėti, kaip Rusijos taikdariai užtikrina ugnies nutraukimo režimo vykdymą .

Išaugus tarptautinès bendruomenės dėmesiui Abchazijos konfliktui, i jo sureguliavimą ịsitraukẻ JT generalinio sekretoriaus „draugu grupe “, kurią sudarè JAV, Didžiosios Britanijos, Vokietijos, Prancūzijos ir Rusijos diplomatai. „Draugu grupès“ paskirtis buvo tarpininkauti, padedant konflikto šalims siekti kompromiso.

Pietų Osetijos atveju tokios aršios įtampos tarp tautų kaip Abchazijoje nebuvo. Pietų Osetija taip pat nėra istorinis Gruzijos regionas. $1922 \mathrm{~m}$. ji buvo prijungta prie Gruzijos atskiriant ją nuo Šiaurès Osetijos (kuri priklausè Rusijos SSR). 1989 m. Pietų Osetijos Aukščiausioji Taryba paprašẻ Tbilisio suteikti Pietų Osetijai autonominès respublikos statusą (kaip Abchazijos), tačiau išreiškè norą likti Gruzijos sudètyje ${ }^{9}$. Kadangi Gruzijoje tuo metu vyravo radikalios nacionalistinès nuotaikos, Pietų Osetijos prašymas buvo atmestas. Dar daugiau, iš Pietų Osetijos buvo nuspręsta atimti autonominio regiono statusą. Prezidentas Eduardas Ševardnadzè šį žingsnį vèliau pavadino „didžiausia Gruzijos klaida“. Tai sukèlè karinį regiono pasipriešinimą. Prasidejję 1990 m., kariniai veiksmai buvo ,į̌saldyti“ 1992 m., Ševardnadzei ir Rusijos prezidentui Borisui Jelcinui pasirašius susitarimą dèl ugnies nutraukimo ${ }^{10}$. Tais pačiais metais Pietų Osetijoje buvo dislokuotos taikdariškos pajėgos, sudarytos iš Gruzijos, Rusijos ir Pietų Osetijos taikdarių. Taikdarių veiklą turèjo prižiūrèti Jungtinės kontrolès komisija, kurią sudarè Gruzijos, Rusijos, Šiaurès Osetijos ir Pietų Osetijos atstovai. Gruzija nuolat kèlè reikalavimą pakeisti šią asimetriją, kurioje Rusijai teko trys balsai. Tačiau asimetrija galëjo būti keičiama tik visų jo dalyvių bendru sutarimu, todèl to niekada ir nebuvo padaryta.

Rusija ,į̌šldytų“" konfliktų zonose plètė savo įtaką, didindama šių regionų de facto integraciją i Rusiją. Pirma, separatistiniai regionai karo su Gruzija metu buvo visokeriopai remiami Rusijos ${ }^{11}$. Antra, net ir pasirašius susitarimus dèl ugnies nutraukimo, Rusija nenustojo ginkluoti separatistinių regionų tam, kad taikos procesas užsitęstų kiek įmanoma ilgiau. Trečia, Rusija rẻmè regionų de facto režimus. Pavyzdžiui, de facto valdžios atstovams atlyginimai dažnai išmokami Rusijos. Dar daugiau, Rusija, kurios piliečiais yra daugiau nei 80

\footnotetext{
8 Bartuzi W., et. al. Abkhazia, South Ossetia and Nagorno-Karabakh: frozen conflicts between Russia and the West, Warsaw: Centre for Eastern Studies, 200807 09, p. 5.

9 Sabanadze, (nuoroda 6) p. 15.

${ }^{10}$ Lynch, (nuoroda 7) p. 18.

${ }^{11}$ Sabanadze, (nuoroda 6) p. 13, 17.
} 
proc. Abchazijos ir Pietų Osetijos gyventojų ${ }^{12}$, šiems mokëjo pensijas, pašalpas ir kitas išmokas. Ketvirta, Rusijos verslo įmonės yra gerai įsitvirtinusios separatistiniuose regionuose. Taigi Rusija pilietybės, socialinės, ekonominės ir karinės politikos pagalba privertė separatistinius regionus vis labiau gravituoti Rusijos link (Pietų Osetija ne kartą yra išsakiusi norą prisijungti prie Rusijos), taip sunkindama galimą reintegraciją su Gruzija.

Rusijos politika etniškai skirtingų regionų atžvilgiu - dvilypè. Savo teritorijoje Rusija kalba apie totalu teritorinio integralumo principą, neketindama daryti jokių nuolaidų Šiaurès Kaukazo respublikoms. Tačiau kaimyninių valstybių atžvilgiu Rusijos „,susirūpinimas“ etninių mažumų teisėmis labai išauga. Taip yra todèl, kad separatistiniai konfliktai - vienas galingiausių Rusijos svertų įtakai posovietinėse valstybėse išlaikyti. Gruzija, kaip ir Azerbaidžanas, po nepriklausomybės atkūrimo nusprendè nestoti į Nepriklausomų valstybių sandraugą (NVS). Po karo Abchazijoje Rusija paragino Gruziją tapti NVS nare bei pasirašyti dvišalį susitarimą dèl keturių Rusijos karinių bazių dislokavimo Gruzijos teritorijoje. Tai, kad Rusija yra veikiau separatistinių konfliktu šalis nei tarpininkè, rodo ir tai, kad susitarimai dèl ugnies nutraukimo, kuriuos parastai pasirašo konflikto šalys, buvo pasirašyti Gruzijos ir Rusijos.

\section{2. Ševardnadzès balansavimas tarp Maskvos ir Vakarụ}

Atkūrusi nepriklausomybę, Gruzija pasirinko provakarietišką užsienio ir saugumo politikos kryptį ir $1992 \mathrm{~m}$. tapo Śiaurès Atlanto bendradarbiavimo tarybos nare. Tačiau 1993 m. pabaigoje po nesèkmingo karo Abchazijoje Gruzija buvo priversta stoti i NVS. Nors prisijungimas prie Rusijos dominuojamos organizacijos apribojo provakarietiškos Gruzijos politikos galimybes, visgi 1994 m. šalis sėkmingai įsitraukè į Partnerystės taikos labui (angl. Partnership for peace - Pfp) programą.

Visą paskutiniji dešimtmetị Gruzija buvo priversta balansuoti tarp siekio intensyviau bendradarbiauti su NATO bei būtinybès „neerzinti“" Rusijos, kurios įtaka dèl separatistinių Abchazijos ir Pietų Osetijos konfliktų šalyje ypač išaugo. Dar daugiau, Gruzija tuo metu buvo visiškai priklausoma nuo Rusijos tiekiamu dujų ir naftos.

Ševardnadzės pastangos išlaikyti balansavimą tarp Maskvos ir Vašingtono davè neblogu rezultatu Jelcino laikais, tačiau Rusijos prezidentu tapus Vladimirui Putinui, Rusijos spaudimas Gruzijai èmè didèti. 2000 m. pabaigoje, atsakydama į neva pernelyg provakarietišką Gruzijos politiką, Rusija Gruzijai i̇vedè vizų režimą ${ }^{13}$. Svarbu tai, kad vizų režimas Abchazijai ir Pietų Osetijai ivestas nebuvo, taip dar labiau atskiriant separatistinius regionus nuo Gruzijos ir priartinant juos prie Rusijos.

\footnotetext{
${ }^{12}$ Bartuzi W., et.al., (nuoroda 8) p. 5-6.

${ }^{13}$ Falkowski M., Russia's policy in the Southern Caucasus and Central Asia, Warsaw, Centre for Eastern Studies, June 2006, p. 51.
} 
1999 m. Stambule vyko ESBO viršūnių susitikimas, kuriame Rusija prisiėmè įsipareigojimą išvesti savo karines bazes iš Gruzijos ir Moldovos teritorijų. Tačiau šiuos įsipareigojimus Rusija ilgą laiką tiesiog ignoravo (iš Gruzijos Rusijos karinės bazės buvo išvestos tik $2007 \mathrm{~m}$. antroje pusëje). Gruzijos nepasitenkinimas Rusijos politika nuolat augo.

İtampa tarp Rusijos ir Gruzijos pradèjo didèti 1999 m., antrojo Čečènijos karo metu. Rusija kreipèsi ị Gruziją su prašymu ịvesti kariuomenę i Gruzijos teritoriją ir iš Gruzijos-Čečènijos sienos pusès pulti Čečèniją (Gruzija - vienintelè užsienio valstybė, su kuria ribojasi Čečénija). Be to, Rusija prašè leidimo pasinaudoti Vazianio kariniu oro uostu (netoli Tbilisio) ir Rusijos karinemis bazėmis, dislokuotomis Gruzijoje, vykdant karinius veiksmus prieš Čečėniją. Šiuos prašymus Rusija grindè įtarimais, kad čečènų separatistai pastiprinimą gauna per Čečènijos-Gruzijos sieną, einančią Didžiaisiais Kaukazo kalnais. Gruzija šiuos Rusijos prašymus atmetė kaip neturinčius pagrindo, nes, pasak Gruzijos atstovu, pereiti Gruzijos-Čečènijos sieną - labai sudètinga, o žiemą Didieji Kaukazo kalnai yra visiškai nepereinami. Kalbèti apie ginklų pergabenimą kalnais einančia siena iš viso nèra prasmès ${ }^{14}$.

2002 m. Rusija vẻl kreipėsi į Gruziją, reikalaudama leidimo įvesti savo karinius dalinius į Pankisio tarpekli, kuriame neva slapstosi Čečènų teroristai ${ }^{15}$. Gruzija, atsakydama į Rusijos ịtarimus, nutarè neįsileisti Rusijos kariu, o pati surengti saugumo operacijas Pankisio tarpeklyje. Per $2002 \mathrm{~m}$. buvo surengtos dvi saugumo operacijos - sausio ir rugpjūčio mėnesį. Ju metu nepavyko aptikti nè vieno tarpeklyje besislapstančio čečènu teroristo. Rusija netruko sukritikuoti Gruzijos vykdytas operacijas tarpeklyje kaip demonstracinio pobūdžio ir neefektyvias.

Tiek Gruzijai, tiek JAV nerimą kèlė Rusijos oro pajègų vykdomi nesankcionuoti Gruzijos oro erdvės pažeidimai. Ne vieną kartą Rusijos karinės pajėgos, neva netyčia patekusios į Gruzijos oro erdvę, bombarduodavo gruzinų kaimus. $2002 \mathrm{~m}$. rugpjūčio pabaigoje, po paskutinès Gruzijos vykdytos saugumo operacijos Pankisio tarpeklyje, Rusijos karinės oro pajègos įsiveržè i Gruzijos teritoriją ir savarankiškai bombardavo tarpekli. Tai buvo paskutinis žingsnis, privertęs Ševardnadzę ryžtingiau pasukti NATO link.

$2002 \mathrm{~m}$. lapkričio $1 \mathrm{~d}$. speciali vyriausybinè komisija parengė Gruzijos integracijos i NATO programą karinejje, politinejje ir ekonomineje srityse. Tu pačiu metų Prahos NATO viršūnių susitikimo metu Gruzija viešai deklaravo siekį ateityje tapti NATO nare bei dalyvauti naujoje programoje - Individualios partnerystės veiksmu plane (angl. Individual Partnership Action Plan-IPAP).

\footnotetext{
${ }^{14}$ German T., Faultline or Foothold? Georgia 's relations with Russia and the USA. Conflict Studies research Center, UK Defence academy, January 2004, p. 2-3.

${ }^{15}$ Ten pat, p. 3 .
} 


\section{Go West!: narystè NATO kaip saugumo strategijos leitmotyvas}

\subsection{Saakašvilio pergalè ir NATO narystès siekis}

2003 m. pabaigoje, įvykus masiniams protestams dèl sisteminiu rinkimu tvarkos pažeidimu, Sevardnadzės režimas buvo priverstas trauktis. Po naujai surengtų rinkimu, gavęs absoliučią balsų daugumą, i̇ valdžią atėjo provakarietišku pažiūrų Michailas Saakašvilis.

Saugumo politikoje Ševardnadzės režimas susidūrè su keletu sunkumų. Didžiausias sistemos bei režimo apskritai trūkumas buvo tas, jog Gruzija nekontroliavo savo sienų: separatistiniai Abchazijos ir Pietų Osetijos regionai veike kaip ,juodosios skylès", kurių sienos kirtimas buvo visiškai nekontroliuojamas. Dar daugiau, trūko dėmesio bei lèšu vidaus jẻgos ir saugumo struktūroms.

Saakašvilio režimo leitmotyvu tapo šalies narystè NATO. Kaip jau buvo minèta, dar Ševardnadzės prezidentavimo metais pastebimas polinkis labiau remtis JAV nei Rusija saugumo politikoje, tačiau šis balansavimas į sistemingą provakarietišką orientaciją, kaip pagrindinị saugumo strategijos vektoriu taip ir neperaugo. Tuo tarpu tik į valdžią atèjęs Saakašvilis ryžtingai pasuko provakarietiška kryptimi, narystę NATO įvardinęs kaip pagrindinį Gruzijos užsienio ir saugumo politikos tiksla..

Labai svarbu pastebèti, kad be provakarietiško politinio elito Gruzijoje įsigalëjimo šalies suartėjimą su NATO lèmè ir išorinis veiksnys - Gruzijos svarbos Vakarams didejjimas. Be jokiu abejoniu kad būtent JAV interesai šiame regione verte skirti didesnį demesį Gruzijai. Ši svarba augo dèl kelių priežasčių:

- Po NATO plètros 2004 m. Aljansas Gruziją èmé vertinti kaip svarbią grandị, užtikrinančią stabilumą Pietų Kaukazo regione. Neišspręsti konfliktai tarp Azerbaidžano ir Armėnijos, „ǐ̌aldyti“ santykiai tarp Armėnijos ir Turkijos, potencialaus Gruzijos regionų separatizmo grėsmé nuolat kèlè nerimą, kad šis regionas gali tapti nauju, vienos valstybės ribas peržengiančių konfliktų židiniu.

- JAV vis labiau klimpstant i konfliktą Irake bei aštrëjant situacijai dèl Irano, smarkiai išaugo strateginė Pietų Kaukazo reikšmè. Potenciali parama Irako stabilizavimo poreikiams ir ypač - galimo konflikto su Iranu atveju - padidino JAV dėmesị Gruzijai.

- Buvo manoma, kad provakarietiška Gruzija, remiama Aljanso, galètu atlikti barjero, stabdančio Rusijos įtakos plitimą Pietų Kaukaze, funkciją. Greta Ukrainos, kuri tuoj išgyvens „Oranžinę revoliuciją" ir taip pat sustiprinus savo provakarietišką orientaciją, Gruzija tapo svarbia Rusijos ekspansijos sulaikymo grandimi.

- Gruzija Vakarams tapo aktuali dèl energetinių projektu, vykdomų Pietu Kaukaze. Ypač svarbią vietą užima energetinių žaliavų transportavimo 
projektai. Azerbaidžano, turinčio dideles naftos ir dujų atsargas, pastangos šias žaliavas į pasaulio rinką transportuoti ne tik per Rusiją, pavertė Gruziją reikšminga tranzito grandimi ir dar labiau padidino Vakarų susidomẹjimą šalimi. 2006 m. viduryje èmé funkcionuoti naftotiekis Baku-Tbilisis-Džeichanas, 2006 m. pabaigoje - dujotiekis Baku-Tbilisis-Erzurumas.

Nors ne visos NATO šalys vienodai vertino Gruzijos pastangas tapti NATO nare, tačiau akivaizdus JAV dominavimas aljanse turëjo įtakos ganėtinai sparčiai besiplètojančiai NATO ir Gruzijos darbotvarkei.

2004 m. Gruzija pasirašė Individualios partnerystès veiksmų planą (IPVP) su NATO. IPVP pasirašymas ženklino antrajį Gruzijos etapą kelyje i NATO. IPVP apėmė keturias sritis: politikos ir saugumo klausimus, gynybos politikos ir karinius klausimus, viešosios informacijos, mokslo bei aplinkos saugos klausimus ir civilinį krizių valdymą, administracinį, gynybos, saugumo ir resursų valdymą. Pasirašius IPVP, pasidejjo intensyvūs pasiruošimo darbai. 2005 m. buvo sukurta speciali komisija, turëjusi prižiūrèti plano ígyvendinimo procesą.

Vienas svarbiausių aspektų kelyje į NATO buvo strateginių dokumentu sistemos saugumo politikos srityje sukūrimas. Ševardnadzė vengè rengti šiuos dokumentus, nes juose turëjo būti užfiksuoti ilgalaikès saugumo politikos kryptys ir prioritetai. Turint omenyje tuometinį Gruzijos balansavimą, kai Rusijos pagrindiniu partneriu saugumo srityje įvardinti nenorima, o JAV - negalima, kitos išeities, kaip tik atidèlioti ši procesą, ir nebuvo.

Tačiau po „Rožių revoliucijos“ 2005 m. Gruzijos Parlamentas prièmė ir Prezidentas patvirtino pirmąą šalies Nacionalinio saugumo strategiją, kuri veikia kaip pagrindinis strateginis šalies dokumentas. $2006 \mathrm{~m}$. Nacionalinio saugumo strategija buvo pakoreguota, teritorinės gynybos principą pakeičiant visuotinès ir besąlygiškos gynybos principu ${ }^{16}$. Taip pat 2005 m. pabaigoje buvo priimta ir Nacionalinė karinė strategija, kurioje pagrindiniu tikslu buvo iškelta narystė NATO kaip sẻkmingos atgrasinimo politikos garantas. Strateginių saugumo politikos dokumentų sistemą užbaigia Grèsmių vertinimo dokumentas ${ }^{17}$, kuris yra peržiūrimas kasmet.

Visuose minètuose strateginiuose dokumentuose pabrèžiama, kad Gruzija siekia tapti JAV dominuojamos kolektyvinio saugumo struktūros - NATO-dalimi ir pareiškiama, kad šalis neketina skirti papildomų išteklių Rusijos dominuojamų struktūru (kalbama konkrečiai apie NVS) plètrai ${ }^{18}$. Lojalumą JAV taip pat įrodo ir faktas, kad Gruzija, turèdama gana silpnas karines pajègas, vis vien siekia aktyviai prisidèti prie JAV vykdomų karinių operacijų. Toks Gruzijos demonstruojamas superlojalumas JAV neabejotinai duoda teigiamų politinių ir ekonominių rezultatų šaliai. Pastaraisiais metais Gruzija tapo viena pagrindinių JAV paramos

\footnotetext{
${ }^{16}$ Ministry of defence of Georgia, Strategic Defence Review. Final report 2007 unclassified, http://www. mod.gov.ge/2007/downloads/The_Strategic_Defence_Review(www.mod.gov.ge).pdf, 200809 10, p. 65.

${ }^{17}$ Ten pat, p. 65.

${ }_{18}$ National Security Concept of Georgia, Tbilisi, 2006, http://www.mod.gov.ge/?1=E\&m=3\&sm=1, 2008 0420.
} 
gavëjų. Nuo 1992 m., kai Gruzijoje pradëjo veikti JAV paramą ekonominëje bei visuomeninejje srityse administruojanti agentūra USAID, Gruzijai suteikta 774 mln. JAV doleriu paramos ${ }^{19}$. Dar daugiau, 2008 m. rugsẻji JAV Kongresas patvirtino 1 mlrd. JAV doleriu paramą (neįtraukia paramos kariniam sektoriui), kuri po karo su Rusija nukentejusiai šaliai bus suteikta per dvejus metus. Pažymėtina, kad ši suma tris kartus viršija JAV paramą, per metus skiriamą visam Pietu Kaukazo ir Vidurio Azijos regionui ${ }^{20}$. Reformoms karo srityje Gruzija (kaip ir kitos Pietų Kaukazo šalys) gauna kasmetinę dotaciją iš JAV biudžeto. Be to, dèl bendradarbiavimo su NATO Gruzijai teikiama parama JAV iniciatyva įkurtame „Pagalbos Pietų Kaukazui koordinavimo forume“ (angl. South Caucasus Clearing House), į kurị susirinkusios donorès siūlo savo pagalbą, o paramos gavejjos renkasi, kokia parama reikalinga. Tačiau besalyginis Gruzijos rèmimasis JAV tuo pat metu sukelia ir keletą rizikos faktorių. Pirma, kyla abejoniu, ar ilgai Gruzijos svarba JAV bus išskirtinè ir kaip pasikeistu JAV požiūris į Gruziją, jei tektų ieškoti Rusijos paramos, sprendžiant kitas tarptautines problemas. Šiuo atveju išlieka rizika, kad JAV vardan Gruzijos gali nesiryžti gadinti santykių su Rusija ${ }^{21}$. Antra, kyla pagrịstų abejoniu, ar JAV, patyrusi ekonominę recesiją, bus linkusi ir toliau taip stipriai finansiškai remti Gruziją, kuri dar tik įpusejjusi reformų kelyje.

2006 m. rudeni, praejjus dviems metams po IPVP pasirašymo (būtent tiek iprastai trunka IPVP igyvendinimas), Vašingtone vykusio NATO valstybių narių užsienio reikalų ministrų susitikimo metu buvo nuspręsta pradèti su Gruzija intensyvų dialogą. Intensyvaus dialogo suteikimas šaliai žymi padèties pokytį nuo šalies Aljanso partnerès link kandidatės. Intensyvus dialogas - dvišalis, skirtas pasirengti Narystès veiksmu plano (angl. Membership Action Plan - MAP) suteikimui.

Daugiausia vilčių Gruzija siejo su 2008 m. balandžio 2-4 d. Bukarešte vykusiu NATO viršūnių susitikimų. Buvo tikimasi, kad galbūt jau šiame susitikime Gruzijai (ir Ukrainai) bus pasiūlytas Narystės veiksmų planas. Šios viltys nebuvo pateisintos, nes NATO šalių lyderiai nesusitare dẻl NVP suteikimo Ukrainai ir Gruzijai, nors buvo nurodyta, kad ateityje šios dvi šalys taps NATO naremis. ${ }^{22}$

Vis dèlto stiprios Gruzijos pastangos ir nemaža pažanga bendradarbiavime su NATO (JAV) leido pagrįstai tikètis, kad Gruzija gaus tvirtas NATO saugumo garantijas. Sprendimas dèl NVP buvo atidètas iki 2008 m. gruodžio mèn. numaty to NATO šalių užsienio reikalų ministrų susitikimo. Tačiau, kaip vẻliau paaiškẻjo, ir šis susitikimas nesuteikè aiškių gairių Gruzijai dẻl galimybių tapti NATO nare.

\footnotetext{
${ }^{19}$ United States Agency for International development (USAID) Georgia, About Georgia, http://georgia. usaid.gov/index.php?m=7, 20081002.

${ }^{20}$ Eurasiainsight, Kucera J., Georgia: US Congress approves reconstruction aid package for Georgia, 2008 09 30, http://www.eurasianet.org/departments/insight/articles/eav093008b.shtml.

${ }^{21}$ Civil Georgia, Russian, U.S. Diplomats Discuss Conflicts, 20070515 , www.civil.ge, 20070520.

${ }^{22}$ Eastweek, Ukraine, Georgia and Russia on the results of the NATO summit in Bucharest: reactions and forecasts, Issue 13(122), 9 April 2008, Warsaw: Centre for Eastern Studies, p. 4.
} 


\subsection{Bandymai spręsti separatizmo problemą ir santykių su Maskva aštrèjimas}

Saakašvilio režimas iš Ševardnadzès „paveldëjo“" ne tik plačiai įsišaknijusią korupciją, bet ir labai silpną centrinès valdžios įtaką regionams. Kaip pastebejo „The Economist", Ševardnadzès Gruzija labiau panašejo ì atskiru feodų samplaiką nei i̇ modernią unitarinę valstybę ${ }^{23}$. Taigi vieni pirmuju ų Saakašvilio žingsnių buvo skirti didinti administracini efektyvumą bei stiprinti centro ir regionų ryšius.

Adžarija, įsikūrusi Juodosios jūros pakrantėje, po nepriklausomybės atgavimo tapo vienu turtingiausių Gruzijos regionų. Tačiau politinis ir administracinis regiono aparatas buvo ne tik labai korumpuotas, bet ir įsitraukęs i organizuoto nusikalstamumo veiklą. Taigi atëjus į valdžią Saakašviliui, Adžarijos politinį elitą èmė gąsdinti artẻjančios permainos, o regione ėmė aštrèti separatistinės nuotaikos ${ }^{24}$. Pagrindo atsiskirti nuo Gruzijos Adžarija lyg ir neturëjo, nes Adžarijos gyventojai - etniniai gruzinai, kurie, XIX a. okupuoti Osmanu imperijos, perėmė musulmonų tikèjimą ${ }^{25}$. 2004 m. kovą Adžarijoje turëjo vykti rinkimai į regionini parlamentą. Saakašvilis pareikalavo laisvu ir sąžiningų rinkimu, priešingu atveju pagrasino regiono blokada. Adžarijos lyderis Aslanas Abašidzė supanikavo, susprogdino tiltus, jungiančius regioną su likusia Gruzijos dalimi, ir pasitraukè į Maskvą. Parlamento rinkimai Adžarijoje buvo surengti tų pačių metų gegužę. Po jų Gruzija atkūrè savo kontrolę Adžarijoje bei suteikè regionui plačią autonomiją.

Po Adžarijos atvejo sprendimo taikiomis priemonemis Saakašvilis nusprendè analogišką modelį taikyti ir Pietų Osetijos konflikto sureguliavimui. Deja, šiuo atveju rezultatas buvo visiškai priešingas.

Nors Adžarijos atvejis iš pirmo žvilgsnio atrodo panašus į Pietų Osetijos bei Abchazijos situaciją, tačiau Adžarijos konflikto sureguliavimo būdas, leidęs atkurti Gruzijos kontrolę regione, tik padidino kitų separatistinių regionų atotrūkį nuo Gruzijos. Šị rezultatų skirtumą lèmẻ keletas priežasčių:

- Adžarija, skirtingai nei Pietų Osetija ir Abchazija, neturi tiesioginio sąlyčio su Rusija, o tai fiziškai apriboja Rusijos galimybes remti separatistinį regioną.

- Konfliktas tarp Gruzijos ir Adžarijos kilo 2004 m., kai jau buvo susiformavę bent jau minimalūs demokratiniai standartai bei visuomenès elgsenos ,šablonai“. Todèl regionui buvo galima daryti įtaką per spaudimą surengti demokratinius rinkimus į vietos parlamentą. Tuo tarpu tiek Pietų Osetijoje, tiek Abchazijoje konfliktai su Gruzija įsiplieskè tuoj pat po SSRS žlugimo ir šiuose regionuose „užsikonservavo“ SSRSlaiku politinio dalyvavimo modelis. Taigi laisvų ir sąžiningų rinkimų surengimas kaip poveikio separatistiniams regionams ịrankis vargu ar galëjo duoti laukiamų rezultatų.

- Adžarijos konfliktas neturèjo etninio pobūdžio, o tai lèmė, kad regiono vi-

\footnotetext{
${ }^{23}$ Lynch, (nuoroda 7) p. 17.

${ }^{24}$ Ten pat, p. $27-28$

${ }^{25}$ Svante, (nuoroda 5), p. 215
} 
suomenė prieš Gruzijos centrinę valdžią nebuvo neigiamai nusistačiusi. Tuo tarpu Pietų Osetijos ir Abchazijos gyventojai, prisimenantys nacionalistinę Gruzijos politiką bei karus, į centrinę Gruzijos valdžią žiūri su nepasitikëjimu.

Saakašvilis 2004 m. atëjo vadovauti šaliai, turinčiai du ,į̌̌aldytus“ separatistinius konfliktus, kurie ne tik mažino šalies saugumą, bet ir buvo pagrindinè kliūtis Gruzijai sẻkmingai integruotis į euroatlantines struktūras. Taigi šalies teritorinio integralumo atkūrimas tapo vienu pagrindinių Saakašvilio uždavinių. Siekdamas pakeisti valstybei žalingą status quo situaciją, Saakašvilio režimas èmèsi aktyvių veiksmų. Galima išskirti keturias pagrindines šių veiksmų kryptis:

- pirma, Saakašvilis ėmèsi stiprinti vykdomąją valdžią. Buvo sustiprintos prezidento galios. Be to, įkurta valstybės ministro (ministro be ministerijos) konfliktų sprendimo klausimais pareigybė;

- antra, vis labiau buvo stiprinami kariniai šalies pajėgumai. Po „Rožių revoliucijos" buvo nuspręsta mažinti Gruzijos reguliariąsias karines pajègas nuo tuometinių 38 tūkst. iki 20 tūkstančių. Pagal JAV Valstybès departamento Tarptautinio saugumo patariamosios valdybos (angl. International Security Advisory Board - ISAB) rekomendacijas, Gruzijai pakaktų 13-15 tūkst. karių reguliariosios kariuomenès. Tačiau vẻliau karių skaičius buvo nuosekliai didinamas, ir 2007 m. pasiekẻ 32 tūkstančius. Taip pat augo ir išlaidos gynybai (šiuo metu tai - didžiausia biudžeto dalis) bei rezervistų skaičius. 2007 m. rudenį Gruzijos parlamente iškelta iniciatyva karines pajègas padidinti dar 2,5 tūkst. karių ${ }^{26}$. Kadangi pasiruošimo narystei NATO atžvilgiu svarbiau yra karinių pajègų parengimo kokybe், o ne kiekybè, tai toks ginkluotuju pajègų augimas aiškiai signalizavo Gruzijos ryžtą kuo greičiau išspręsti ,išaldytų“ konfliktų problemą, neatmetant ir karinio būdo;

- trečia, Saakašvilio režimas aiškiai atskyrè separatistinių regionų de facto valdžią bei regionu gyventojus. Taigi spaudimas buvo daromas tik de facto valdžios aparatui, tuo tarpu gyventojai buvo vertinami kaip Gruzijos piliečiai;

- ketvirta, siekiant efektyvaus konfliktų sureguliavimo, buvo bandoma kiek įmanoma labiau didinti tarptautinį įsitraukimą. Vienas pagrindiniu uždavinių ,išsaldytų“ konfliktų sureguliavimo procese tapo konfliktų sureguliavimo internacionalizavimas. Deja, internacionalizuoti Rusijos dominuojamų konfliktų sureguliavimas nepavyko, nes sureguliavimo keitimui turi pritarti visi jo dalyviai, taigi ir Rusija bei patys separatistiniai regionai. Tačiau tarptautinį įsitraukimą kitur padidinti pavyko ES tapo didžiausia finansine donore Abchazijai, taikdarių pajègos $\mathrm{Ab}$ chazijoje yra prižiūrimos JT (taip vadinamas "Ženevos procesas"), o Pietų Osetijoje - ESBO.

\footnotetext{
${ }^{26}$ RFE/RL, Fuller L. and Giragosian, R., Georgia: what is behind expansion of armed forces?, 200709 19, http://www.rferl.org/content/article/1078720.html.
} 
Tačiau, nepaisant didelių Gruzijos rodomų pastangu, ,išaldytų Pietu Osetijos ir Abchazijos konfliktų sureguliavimas nejudëjo iš vietos. Dar daugiau, buvo pastebima tendencija, kad minèti regionai vis labiau tolsta nuo Gruzijos. Be to, nesékmingos Gruzijos pastangos atkurti teritorinį integralumą suteikẻ Rusijai prielaidas per Abchaziją ir Pietų Osetiją kištis į Gruzijos vidaus reikalus ir didinti dvišalę îtampą.

Galima teigti, kad susidariusi situaciją sukūrè Gruzijai neišsprendžiamą strategini prieštaravimą: kuo aktyviau Gruzija siekẻ narystės NATO, tuo labiau Rusija aštrino Gruzijos santykius su Abchazija ir Pietų Osetija bei didino šiu regionų de facto integraciją i Rusiją. Tuo pačiu, neišsprendus problemų dèl separatistinių regionu, vis tvirčiau skambejo skeptiku prieštaravimai dèl Gruzijos narystės NATO. Kita vertus, Gruzijos noro tapti NATO nare mažinimas galëjo vesti tik į didesnę Rusijos politinę įtaką ir ilgainiui visiškai sužlugdyti Gruzijos strateginius siekius tapti NATO dalimi.

Gruzijos sprendimas imtis keisti situaciją radikaliomis priemonemis 2008 m. rugpjūčio mèn. galëjo būti paskatintas savotiškos politinès desperacijos. Matydamas, kad politinėmis priemonėmis neįmanoma pakeisti situacijos nei dẻl separatistinių regionų kontrolės, nei dèl abejojančių Gruzijos naryste NATO Vakarų šaliu pozicijos, Saakašvilis galëjo pasirinkti radikalią priemonę situacijai pakeisti. Nepriklausomai nuo to, ką laikytume karo tarp Gruzijos ir Rusijos iniciatore ar provokatore, politinè situacija po $2008 \mathrm{~m}$. rugpjūčio mèn. jau iš esmés skyrėsi nuo tos, kuri buvo $2008 \mathrm{~m}$. balandžio mėnesi.

\section{Narystès NATO pažadas ir Gruzijos demokratijos išbandymai}

\subsection{Lietuva - Gruzijos narystès NATO advokatè}

Lietuva, pati būdama maža valstybe ir turẻdama spręsti mažoms valstybẻms būdingas saugumo užtikrinimo dilemas, jau seniai aktyviai remia Gruzijos pasirinktą saugumo užtikrinimo modelį. Kaip ir Gruzija, tik gerokai anksčiau, Lietuva pasirinko aljanso su didžiaja galia strategiją ir jos sėkmingai laikosi.

Lietuvos narystė NATO 2004 m. tapo savotiška "sẻkmès istorija“, kaip maža valstybè gali per sąlyginai trumpą laiką transformuoti ir modernizuoti savo saugumo sistemą bei integruotis į NATO. Naujajai Gruzijos valdžiai, po „Rožiu revoliucijos“ 2004 m. pradžioje galutinai suformavus naują provakarietišką vyriausybę (2004 m. kovo $28 \mathrm{~d}$. vykusius parlamento rinkimus įtikinamai laimejjo Saakašvilio vadovaujama Nacionalinio Judèjimo - Demokratų koalicija), Lietuvos ir kitų Baltijos šalių narystė NATO sustiprino pasiryžimą kuo greičiau tapti aljanso nare. Tokius Gruzijos siekius Lietuva ne tik palaikè, bet ir tapo bene aktyviausia Gruzijos narystės NATO advokate. 
2004 m. spalio 14 d. Vilniuje Gruzijos prezidento Saakašvilio oficialaus vizito metu buvo pasirašyta „Bendra deklaracija dèl regioninio bendradarbiavimo ir paramos europinei ir euroatlantinei integracijai“" kurioje Lietuva ịsipareigojo remti Gruzijos europinès ir euroatlantinès integracijos siekius bei padèti igyvendinti vidaus reformas ${ }^{27}$. Nuo to laiko buvo sudaryta nemažai dvišalių ir daugiašalių susitarimų bei deklaraciju, kuriose atsispindi akivaizdi Lietuvos parama Gruzijos siekiams kuo greičiau tapti NATO nare. Lietuva rẻmė Gruzijos pastangas transformuoti saugumo ir gynybos sistemą ne tik politiniais, bet ir praktiniais veiksmais. Dar $2001 \mathrm{~m}$. vasario $8 \mathrm{~d}$. Lietuva sudare dvišali susitarimą dèl gynybinio (karinio) bendradarbiavimo su Gruzija, abiejų šaliu gynybos ministrai kiekvienais metais susitinka ir aptaria svarbiausius gynybinio bendradarbiavimo aspektus.

Kaip teigiama Lietuvos krašto apsaugos ministerijos pranešimuose, praktinis bendradarbiavimas šiuo metu koncentruojamas karinio mokymo srityje: Gruzijos karininkai Lietuvos lëšomis mokomi Lietuvos karo akademijoje ir Baltijos gynybos koledže. Be to, Lietuva konsultuoja Gruziją viešuju ryšiu klausimais, logistikos, standartizacijos ir kodifikacijos srityje, dalijasi patirtimi, diegiant naujus komunikacijos standartus, kviečia stebèti pratybų ir į įvairias stažuotes (gynybos planuotojams, protokolo specialistams). Nuo $2006 \mathrm{~m}$. pavasario Lietuva paskyrè specialu patarëją Gruzijos Partnerystės veiksmų plano kūrimo (PVP) klausimais ${ }^{28}$.

Nenuostabu, kad NATO viršūnių susitikime $2008 \mathrm{~m}$. balandžio 2-4 d. Bukarešte Lietuvos atstovai buvo vieni aktyviausiu dalyvių, remiančiu JAV iniciatyvas pasiūlyti NVP Gruzijai (ir Ukrainai). Kaip teigia Lietuvos atstovai, prezidentas Valdas Adamkaus aktyviai prisidëjo prie to, kad būtu pasiektas kompromisas ir galutiniame pareiškimo tekste atsirastu iki šiol precedento neturinti frazè apie tai, kad Ukraina ir Gruzija ateityje taps NATO narèmis ${ }^{29}$. Kaip teigiama NATO viršūnių susitikimo deklaracijoje, NATO šalių lyderiai sutarè, kad Ukraina ir Gruzija taps NATO naremis. Vis dèlto sprendimą, ar pasiūlyti šioms valstybėms narystès veiksmų planą, NATO šalių lyderiai atidëjo. Deklaracijoje buvo nurodyta, kad ši sprendimą gali priimti NATO užsienio reikalų ministrai $2008 \mathrm{~m}$. gruodžio mènesi $i^{30}$. Kartu buvo paminèta ir viena iš sąlygu, kuri gali lemti NATO sprendimą dèl Gruzijos NVP - demokratiniu procesų užtikrinimas per Gruzijos 2008 m. gegužès mėn. vyksiančius parlamento rinkimus.

\footnotetext{
${ }^{27}$ Lietuvos Respublikos užsienio reikalų ministerija. Lietuvos ryšiai su Gruzija, http://www.urm.lt/index. php?-1615992752, 20081004.

${ }^{28}$ Lietuvos Respublikos krašto apsaugos ministerija. Bendradarbiavimas su ne NATO šalimis. http://www. kam.lt/accessibility/index.php/lt/144572/.

${ }^{29}$ Lietuvos Respublikos Prezidento spaudos tarnyba, ,Atejo laikas čia ir dabar pakviesti Gruzija ir Ukraina pradèti igyvendinti NATO Narystès veiksmu planq “, - sako Prezidentas V. Adamkus Šiaurès Atlanto Tarybos Viršūniu susitikime, 200804 03, http://www.president.1t/1t/news.full/8919.

${ }^{30}$ Bucharest Summit Declaration. Issued by the Heads of State and Government participating in the meeting of the North Atlantic Council in Bucharest on 3 April 2008, http://www.nato.int/docu/pr/2008/p08-049e. html.
} 


\subsection{Narystès NATO pažadas neišspręstụ dilemų fone}

Kaip tik Bukarešte išryškejjo aiškūs pozicijų skirtumai tarp NATO šalių. JAV, kartu su artimiausiais sajungininkais britais, lenkais bei Baltijos šalių atstovais, akivaizdžiai protegavo Gruzijos ir Ukrainos siekius kuo greičiau gauti NVP. Tuo tarpu tradiciškai Rusijos bandantys neerzinti Prancūzijos, Vokietijos, Italijos vadovai aiškino, kad ši kartą būtina atsižvelgti ir ị Rusijos interesus bei neskubèti su Gruzijos ir Ukrainos narystės NATO perspektyvomis. Jau prieš Bukarešto susitikimą buvo aišku, kad šių dviejų skirtingų pozicijų nebus galima taip lengvai suderinti.

Argumentu, kodèl nedera skubèti su NVP suteikimu Ukrainai ir Gruzijai skeptikai turèjo pakankamai. Didžiausia Ukrainos problema buvo įvardijamas vidinis politikos nestabilumas, ryškus visuomenės susiskaldymas ir menka viešoji parama narystei NATO. Esminiu Gruzijos trūkumu laikytas nesugebëjimas išspręsti teritorinių konfliktų taikiu būdu ${ }^{31}$.

Pasitikèjimą Gruzija sumažino ir 2007 m. pabaigos Gruzijos politinė krizė, kurios metu prezidentas Saakašvilis privertė suabejoti savo ištikimybe demokratijai. Nuo $2007 \mathrm{~m}$. rugsẻjo pabaigos vykę opozicinių partiju protestai apogëju pasiekè lapkričio pradžioje, kada prieš vieno mitingo dalyvius policija panaudojo jègą. Kilę neramumai paskatino prezidentą Saakašvilị lapkričio $7 \mathrm{~d}$. paskelbti nepaprastajją padėti: buvo uždrausti politiniai susirinkimai, nevalstybinių televizijų transliacijos ${ }^{32}$. Prezidentas ir jo atstovai mégino aiškinti, kad politinius neramumus galëjo surežisuoti Rusija ir nepaprastoji padètis buvo būtinybė, siekiant išlaikyti politinį stabilumą. Tačiau šį kartą net artimiausi sajungininkai amerikiečiai suabejojo Rusijos įsitraukimu į Gruzijos vidaus politiką ${ }^{33}$. Gruzijos rẻmëjai, įskaitant ir Lietuvą, paragino Saakašvili laikytis demokratijos principu ir nurodè, kad atidžiai seks 2008 m. sausį vyksiančius Gruzijos prezidento rinkimus.

2007 m. pabaigos įvykiai atskleidè kontraversišką, tačiau ilgą laiką gana sẻkmingą Saakašvilio taktiką palaikyti Vakarų dèmesị. Periodiškai atsinaujinanti įtampa su Rusija ir nuolat iš Tbilisio skelbiamas pavojus dèl Rusijos grèsmès vertẻ sajungininkus Vakaruose, ir ypač JAV „nenuleisti akių“ nuo Gruzijos. Galima būtų manyti, kad ịtampos palaikymas atitiko Tbilisio interesus, o kai kada galbūt net buvo skatinamas. Tik būdama nuolatinès ittampos židinyje ar net balansuodama ant konflikto ribos Gruzija galëjo tikètis išskirtinio JAV dèmesio. Priešingu atveju amerikiečiai, užsièmę konfliktais Irake, Afganistane, problemomis su Iranu, galëjo paprasčiausiai „pamiršti“ apie Gruziją.

Kita vertus, $2007 \mathrm{~m}$. pabaigoje ịvykusi politinè krizè privertè suabejoti Gruzijos vadovų racionalumu. Ne visada pagrịstas Rusijos grèsmės akcen-

\footnotetext{
${ }^{31}$ Rytų Geopolitikos studijų centras. „Kokị poveikị NATO viršūnių susitikime Bukarešte priimti sprendimai gali turèti geopolitiniams procesams Rytu erdvèje?“, žr. Rytu Pulsas, Nr. 1 (3), 200804 04, http://www. rytugeopolitika.lt/multisites/rytugeopolitika/images/stories/rytu_pulsas13.pdf.

${ }^{32}$ BBC, Georgia under state of emergency, 200711 08, http://news.bbc.co.uk/2/hi/europe/7083911.stm.

${ }^{33}$ REUTERS, U.S. says doubts Russia involved in Georgia strife, 200711 13, http://www.reuters.com/article/ worldNews/idUSL1367375720071113.
} 
tavimas dar labiau sustiprino skeptiškai į Gruzijos narystę NATO žiūrinčių Europos šalių abejones. Kaip parodè įvykiai 2008 m. rugpjūčio mèn., Gruzija buvo labai jautri provokacijoms iš Rusijos pusès ir greičiausiai pasirinko neadekvatų sprendimą bei neapskaičiavo Rusijos reakcijos.

Vis dèlto vienas pagrindinių faktorių, didinančių Gruzijos patrauklumą aljansui, yra tai, kad Gruzija iš bendro Pietų Kaukazo konteksto išsiskiria ypač stipriu europietišku identitetu. Jei Armėnija, silpniau ir Azerbaidžanas, reiškia norą būti vertinami kaip priklausantys Europai, tai Gruzija aiškiai save sieja su europietiškaja civilizacija ir ryžtingą siekį įsilieti į Europos valstybiu šeimą ${ }^{34}$. Tokia stipri Gruzijos saviidentifikacija veikia kaip savotiškas "garantas" Vakarams, kad šalis, pasikeitus kaštų ir naudos balansui, nepasuks glaudaus bendradarbiavimo su kita didžiąja galia (Rusija) link, t. y. egzistuoja mažesnè grèsmè, kad Vakarų politikos „įdirbis“ Gruzijoje bus lengvai eliminuotas.

Pastaruosius kelerius metus Gruzija gana sparčiai ir sėkmingai reformavo karinį sektoriu (apie ką liudija ir perèjimas nuo IPAP prie intensyvaus dialogo 2006 m.). Daugelis kariniu reformų buvo nukreipta NATO standartų kryptimi, ypač buvo didinamas pasirengimas tarptautinèms krizių valdymo operacijoms. Kita vertus, tai gerokai sumažino dèmesį Gruzijos pasirengimui vykdyti teritorinę gynybą ar dalyvauti dideliuose konvenciniuose mūšiuose. Kaip tik po karo su Rusija kilo abejoniu, ar pasirinkta kariuomenės reformos kryptis buvo pakankamai apskaičiuota ir tokiai valstybei kaip Gruzija iš esmès tinkama. Gruzija šalies viduje pasiliko nedidelę profesionalią kariuomenę, kai tuo tarpu pagrindinès pajègos buvo rengiamos tarnauti NATO misijose (Irake buvo dislokuota 2000 Gruzijos kariu). Gruzijos vidaus kariuomenè buvo sudaroma iš rezervistu, kurie baigdavo minimalius mokymus. JAV Valstybės sekretorės pavaduotojo Europos ir Eurazijos klausimais padejjèjas Matthew Bryza pareiškè, kad po karo Gruzijai galbūt vertètų pagalvoti apie naują karinių pajègų struktūrą ${ }^{35}$.

NATO generalinis sekretorius Jaap de Hoop Schefferis 2008 m. rugsëjo mènesi vykusio vizito metu pabrèžè, kad kelias į narystę NATO Gruzijai lieka atviras, tačiau tolesnès reformos yra būtinos. Shefferis šalies vadovybei priminè ir ne be priekaištų įvykusius parlamento rinkimus, ir gana lètą demokratizacijos kelią ${ }^{36}$.

Rusijos ir Gruzijos konfliktas, įsiplieskęs 2008 m. rugpjūti, sukèlè didžiuli nerimą Vakaruose, tačiau kartu iškèlè ir daugybę klausimų dèl Gruzijos saugumo ateities. NATO šalių vadovai susidūrè su rimta dilema: ar pasiduoti moraliniam Gruzijos spaudimui kuo greičiau priimti šią šalị i kartu ir prisiimti atsakomybę už dar bemaž „karštą“" Pietų Osetijos konfliktą ar neskubèti teikti visų Aljanso saugumo įsipareigojimų Gruzijai ir tuo pačiu netiesiogiai patvirtinti, kad Rusija sugebėjo užblokuoti NATO sprendimus dèl plètros.

\footnotetext{
${ }^{34}$ Tsisikarishvili S., „On the Southern Caucasus’ perspectives of becoming Euro-Caucasus“ in Lithuanian Foreign Policy Review, No. 17, 2006, p. 144-151, 144-145.

${ }^{35}$ Eurasia Insight, Kucera J., Georgia: US Congress approves reconstruction aid package for Georgia, 2008 09 30, http://www.eurasianet.org/departments/insight/articles/eav093008b.shtml, 20081005.

${ }^{36}$ Eurasia Insight, Lomsadze, G., NATO to Georgia: membership road still „, open “, but reform needed, 2008 09 16, http://www.eurasianet.org/departments/insight/articles/eav091608f.shtml.
} 


\subsection{Rizikingos strategijos paradoksai}

Po NATO viršūnių susitikimo Bukarešte Gruzijai duoto narystės Aljanse pažado Rusijos politika Gruzijos atžvilgiu ėmè darytis vis „,nervingesne““. Tačiau kadangi įtampos augimas šių dviejų kaimynių santykiuose pastaruosius keletą metų buvo tapęs beveik norma $(2006 \mathrm{~m}$. draudimas vyno ir mineralinio vandens importui, 2007 m. šnipų skandalas Rusijos ambasadoje Gruzijoje ir t. t.), pastarasis įtampos augimo periodas atrodè „eilinis“ ir neleido identifikuoti grėsmingų Rusijos užmačių.

Rugpjūčio pradžioje Saakašvilis nusprendẻ imtis konkrečių veiksmų šalies teritoriniam integralumui atkurti ir įvedẻ karines pajejgas į Pietų Osetiją. Rusija tokio Gruzijos vadovybės sprendimo tik ir telaukè: "suvaidinusi“, kad operatyviai reaguoja į veiksmus prieš savo piliečius, Rusija įvedè savo jau kurị laiką koncentruotas karines pajègas. Daugelis karinių ekspertų sutinka, kad, jei Rusija iš tikrujų būtų tik reagavusi ị Gruzijos veiksmus, kariniai veiksmai būtų prasidėję gerokai vẻliau. Jau vien tai, kad Rusija dar iki rugpjūčio sutelkẻ dideles karines pajėgas prie Pietų Osetijos sienos, leistų tvirtinti, kad buvo laukiama itampos eskalacijos.

Kariniai veiksmai tarp Rusijos ir Gruzijos prasidejjo rugpjūčio 8 d. ir truko iki rugpjūčio 22 dienos. Nors Rusija teigè, kad ji "gynë" savo piliečius Pietų Osetijoje, iš jos veiksmu buvo akivaizdu, kad tai buvo karas prieš Gruziją. Rusija turëjo dvi atsako į Gruzijos veiksmus Pietų Osetijoje galimybes: išstumti Gruzijos karines pajègas iš Pietų Osetijos ribų (tada tai su išlygomis būtų galima laikyti piliečių apsauga), arba, kaip ji ir pasielgè, karinius veiksmus išplèsti visoje Gruzijos teritorijoje. Pastarasis variantas pagristai leido apkaltinti Rusiją karu prieš suverenią valstybę ${ }^{37}$. Neabejojama, kad Rusija seniai laukẻ tinkamos progos „nubausti“ Gruziją. Galima teigti, kad šis karas Rusijai buvo reikalingas dèl keleto tikslų:

- įbauginti tiek Gruzijos valdantiji režimą, tiek visuomenę, parodant, kas būna, jei nepaisoma Rusijos interesų;

- fiziškai sunaikinti karinę ir ekonominę infrastruktūrą (pvz., visiškai sunaikinta Senakio karinè bazè, Počio uostas, dalis svarbių keliu, geležinkeliu);

- parodyti, kad Gruzija yra nestabili valstybè, kurioje per daug rizikinga plètoti svarbius energetinius, investicinius ar kitus projektus. Tariamas ar tikras Baku-Tbilisio-Džeihano naftotiekio bombardavimas turëjo sukelti nerimą potencialiems investuotojams ir gerokai susilpninti būsimu projektu (pvz., Nabucco dujotiekio plètros) patikimumą;

Kariniai veiksmai tarp šalių buvo sustabdyti tarpininkaujant Prancūzijos prezidentui Nikolas Sarkozy, pasiūliusiam vadinamąji šešių punktų planą. Kaip teigè pats Prancūzijos prezidentas, Europai visų pirma buvo svarbu nu-

\footnotetext{
${ }^{37}$ Emerson M., Post-mortem on Europe's first war of $21^{\text {st }}$ century, Centre for European Policy Studies, Policy brief No. 167, August 2008, p. 1.
} 
traukti tiesioginius karo veiksmus, o ne ieškoti kaltų ar bandyti bausti Rusiją už perdètą jėgos naudojimą. Vis dèlto po karo veiksmų pabaigos Vakaru atstovai (net Vokietijos kanclerė Angela Merkel) pabrěždavo, kad pastarieji Rusijos veiksmai negali paneigti Gruzijos narystès NATO. Tokie padrąsinimai Gruzijai gali būti vertinami dvejopai: a) kaip aiškus apsisprendimas spartinti Gruzijos prièmimą į NATO; b) kaip būtinybė aiškiai parodyti Maskvai, kad ji negali keisti NATO darbotvarkès ar turèti „veto“ teisès sprendimams dèl narystès NATO.

Vis dèlto kiek atslūgus įtampai, Vakaruose imta atsargiau kalbèti apie Gruzijos galimybes tapti NATO nare ir net imta kelti pačios Gruzijos atsakomybės dèl įvykusio konflikto klausimą ${ }^{38}$.

Narystès NATO pažadas, gautas 2008 m. balandį Bukarešte, turèjo „nuraminti“ Gruziją. Tačiau vèlesni įvykiai, pasibaigę rugpjūčio mènesio karu, parodè, kad Gruzijos reakcija ị 2008 m. NATO viršūnių susitikimo rezultatus buvo priešinga nei tikètasi: šalis pažadą priimti i NATO ateityje interpretavo ne kaip sparčiai daromos politinės ir techninès pažangos pripažinimą tarptautiniu lygmeniu, o kaip grèsmingą signalą, kad, skubiai neišsprendus esamų problemų, durys į NATO užsidarys visiems laikams. Nereikia pamiršti, kad Gruzijos atstovai į Bukareštą vyko pasirašyti NVP, t. y. užsitikrinti aiškią narystès Aljanse perspektyvą, o ne išgirsti abstrakčią politinės valios išraišką. Tai, kas kai kurioms NATO narèms ir Rusijai atrodè kaip labai drąsus ir precedento neturintis žingsnis, pačiai Gruzijai galejo skambèti kaip pralaimejjimas.

Kaip jau buvo minėta anksčiau, Gruzijos saugumo strategija yra tarsi „pakibusi“", nes nesiremia jokiomis konkrečiomis saugumo garantijomis. Kaskart augant aspiracijomis, toks „pakibimas“ skatina radikalesnę šalies elgseną. Gruzija santykiuose su NATO iš esmès jau išnaudojo visus savo strateginius argumentus (geopolitinę padèti bei tvirtą provakarietišką identitetą), taigi dar daugiau įtakos Aljanso sprendimui vargu ar galima tikètis. Todèl tokioje situacijoje Gruzijai gyvybiškai būtina arba gauti konkrečias saugumo garantijas, arba imtis peržiūrèti savo pasirinkimus saugumo politikoje.

Dar vienas faktorius, neabejotinai daręs įtaką Gruzijos sprendimui jèga spręsti „į̌saldytus" konfliktus - artëjantys JAV prezidento rinkimai. Prezidento rinkimus laimëjus demokratų kandidatui Barackui Obamai, labai tikètina, kad JAV finansinè parama Gruzijai gali būti apkarpyta. Geriau pasirengti narystei Aljanse su menkesne pagalba Gruzijai būtų labai sudètinga. Tai galejjo paskatinti įsitikinimą tarp Gruzijos politiku, kad NVP bet kokia kaina reikia gauti 2008 m. gruodį vykstančio NATO užsienio reikalu ministrų susitikimo metu.

\footnotetext{
${ }^{38}$ Pavyzdžiui, Europos Tarybos Parlamentinė Asamblèja 2008 spalio 2 d. prièmé rezoliuciją Nr. 1633, kurioje pripažįstama, kad abiejų konfliktų pusių pateikia įvykių versijos yra kontraversiškos, todèl būtinas nepriklausomas tyrimas. Žr. Council of Europe Parliamentary Assembly Resolution 1633 The consequences of the war between Georgia and Russia, http://assembly.coe.int/Main.asp?link=/Documents/AdoptedText/ ta08/ERES1633.htm.
} 
Po to, kai Rusija pripažino Abchazijos ir Pietų Osetijos nepriklausomybę, situacija dar labiau komplikavosi. Viena vertus, Rusija oficialiai èmè laikytis pozicijos, kad Abchazija ir Pietų Osetija jau nebėra Gruzijos dalys, taigi Gruzija su teritorinio integralumo problemomis nebesusiduria. Rusija tarsi igyja legitimą teisę oficialiai užmegzti ryšius su šiais regionais, sudarinèti įvairias tarptautines sutartis, tarp jų -ir karinės pagalbos ar saugumo užtikrinimo susitarimus. Kita vertus, Abchazija ir Pietu Osetija nesulaukia tarptautinès bendruomenès pripažinimo ir vis dar vertinamos kaip Gruzijos teritorijos dariniai. Galima teigti, kad ,'išaldyti“ Gruzijos konfliktai dar labiau ,išalo": anksčiau buvo susiduriama su poreikiu nustatyti separatistiniu regionų statusą, o šiuo metu - dar ir konfliktu tarp tarptautinės sistemos veikëju dèl Abchazijos ir Pietų Osetijos valstybingumo vertinimo. Pastaroji situacija, bent jau tarptautinės teisès prasme, atrodo žymiai sunkiau išsprendžiama nei iki 2008 m. rugpjūčio mèn.: Rusija nebegali atšaukti savo sprendimų dèl Abchazijos ir Pietų Osetijos pripažinimo, o Gruzija ir didžioji dalis tarptautinės bendruomenės negali atsisakyti nuostatos, kad šie dariniai tebèra Gruzijos dalis.

Vis dèlto de facto situacija gali būti suvokiama žymiai paprasčiau. Tiek Vakarai, tiek greičiausiai ir pati Gruzija supranta, kad Tbilisis nebeturi galimybiu grįžti į Abchaziją ir Pietų Osetiją. Tai gali būti vertinama kaip nauja galimybė nebeeikvoti energijos, sprendžiant beviltiškus teritorinius konfliktus, o susitelkti i tvirtesnių NATO garantijų siekimą. Šiuo atveju žvelgiant bent jau iš Gruzijos pusès galima būtų teigti, kad Tbilisis, nors ir labai skausmingu būdu, išsprendè savo dilemą ir aiškiai pasirinko vienintelę alternatyvą: tapti NATO nare net ir be Pietų Osetijos bei Abchazijos. Net jei to ir nebuvo siekta tikslingai, dabartine situacija de facto Gruzijai nebesuteikia kitu galimybių.

\section{Išvados}

Kaip jau buvo minèta, aljanso saugumo strategija ypatinga tuo, kad duoda labai aiškias saugumo politikos gaires bei tvirtą ryši tarp mažosios valstybės bei potencialaus saugumo tiekèjo - didžiosios galios. Tačiau aljanso trūkumas yra tas, kad jis yra nelankstus ir beveik neturi alternatyvų. Tokioje situacijoje, kokioje dabar yra Gruzija, mažajai valstybei nelieka nieko kito, kaip tik nuosekliai vykdyti savo pasirinktą užsienio ir saugumo politiką. Vienintelis dalykas, ką Gruzija gali daryti - laukti grižztamojo sprendimo iš NATO pusès. Vis dèlto šis sprendimas turi būti duotas nedelsiant, nes Gruzija negali neribotą laiką savo saugumo strategiją grịsti tik aspiracijomis. Jei NATO nuspręstų labai aiškiai suteikti Gruzijai narystès perspektyvą, galima būtų teigti, kad Gruzija igyvendino savo siekį bet kokia kaina sukurti patikimus aljanso ryšius su Vakarais ir ypač - JAV. Negatyvaus NATO sprendimo (ar neapibrèžto atidèliojimo atveju) Gruzijos saugumo strategiją gali tekti keisti iš esmès. 2008 metu pabaigoje būtent šis scenarijus atrodẻ labiau tikètinas, nes NATO nariu tarpe abejonių dèl Gruzijos galimybių tapti NATO nare buvo net daugiau nei iki Gruzijos - Rusijos karo. 
Negalima pamiršti ir sudètingos vidinès Gruzijos situacijos. Visiškai įmanoma, kad saugumo strategijos pokyčius inicijuotu jau nauja Gruzijos valdžia. Jei Saakašvilis neigyvendins savo tautai duoto pažado, užtikrinti Gruzijos saugumą per narystę NATO, jam bus sunku išlaikyti pasitikëjimą ir autoritetą.

İvykių Gruzijoje baigtis dar labiau pagilino NATO dilemą bei padidino takoskyrą tarp NATO plètros entuziastų ir skeptikų. Viena vertus, atrodytu, kad NATO plètra po tokių Rusijos veiksmų turètų suintensyvèti, siekiant nenuvilti narystės Aljanse siekiančių šalių. Kita vertus, NATO plètra, turinti padidinti tarptautinės sistemos saugumą, priešingai gali išprovokuoti potencialių kariniu konfliktų bangą (pvz., Krymo problemą), o tai diskredituotu patị Aljansą.

Rusijos sprendimai veltis į karą su Gruzija ir pripažinti Abchaziją bei Pietų Osetiją taip pat atima jai galimybę toliau manipuliuoti , „išaldytu“ konfliktų situacija. Iki šiol buvo laikoma, kad neišspręstas separatistinių konfliktų klausimas yra pats geriausias būdas Rusijai stabdyti NATO sprendimus dẻl Gruzijos. Igyvendinusi savo grasinimus, Rusija išnaudojo ir stipriausius argumentus. Panašiai kaip ir Gruzija, šiuo metu Rusija jau nebeturi galimybių manipuliuoti NATO alternatyvomis ir jai belieka laukti NATO sprendimo dèl galimybių Gruzijai ir Ukrainai ateityje tapti NATO narėmis. Be to, Rusija gerokai sumažino savo patikimumo vertinimus ir dar labiau padidino įtampą su JAV. Žvelgiant globaliau, karas su Gruzija priverte Maskvą taip pat pasirinkti siauresnį kelią, kuris veda į didëjančią konfrontaciją su Vakarais (ar bent jau su JAV). Tai gali privesti Rusiją prie pražūtingos izoliacijos ir neprognozuojamo agresyvumo. Ar Gruzijos narystė NATO verta tokios kainos? Žvelgiant iš Maskvos pozicijų - greičiausiai taip. Matyt, Rusijos užsienio ir saugumo politika vis dar vertinama tik siauru geopolitiniu aspektu. Todèl potencialūs pralaimëjimai Gruzijoje ir Ukrainoje Maskvoje gali būti suvokiami kaip galutinis didžiosios galios statuso praradimas.

Tiek Gruzija, tiek Rusija pasirinko rizikingą strategiją, kuri gerokai suvaržè ju pačiu galimybes ateityje kažką keisti Abchazijos ir Pietų Osetijos atžvilgiu. Kartu tai verčia ir NATO rinktis radikalų kelią, kurị pakeisti jau būtų per daug sudètinga. Turint galvoje, kad svarbiausi NATO sprendimai turi būti priimami bendru sutarimu visada išlieka didesnè tikimybè, kad kompromisas bus pasirinktas nuosaikesnių sprendimo šalininkų naudai. Vis dèlto tai, kas dabar gali atrodyti „,nuosaiku“, ateityje gali būti vertinama kaip pražūtingas neryžtingumas.

Galima apibendrinti, kad aiškus Gruzijos pasirinkimas tapti NATO nare, net ,"aukojant" galimybes atkurti teritorinį vientisuma, nėra pakankama sąlyga, garantuosianti ilgalaikị Gruzijos saugumą. Vien Gruzijos aspiracijų šiuo metu neužtenka, kad būtų ịtikintos visos NATO narès dèl Gruzijos prièmimo į šį Aljansą. Ilgą laiką Tbilisio vykdyta taktika didinti Gruzijos geopolitinę svarbą ir taip išlaikyti JAV dėmesį regione kulminaciją pasiekẻ $2008 \mathrm{~m}$. rugpjūtį. Tačiau kartu tai sukūrè neprognozuojamos ir nepatikimos šalies įvaizdį. Net ir de facto praradusi galimybes susigrąžinti Abchazijos ir Pietų Osetijos kontrolę, Gruzija nepanaikino tos didžiulès rizikos, kuri gali stabdyti NATO prisiimti ìsipareigojimus už Gruzijos saugumą.

Vilnius, 2008 m. rugsëjis-spalis. 